\section{Seed Dimension and Weight of Selected Rubus Species}

\author{
Kim E. Hummer ${ }^{1}$ \\ U.S. Department of Agriculture, Agricultural Research Service, National \\ Clonal Germplasm Repository, 33447 Peoria Road, Corvallis, OR 97333
}

Derek N. Peacock ${ }^{2}$

Department of Horticulture, Oregon State University, Corvallis, OR 97331

Additional index words. blackberry, fruit breeding, genetic resources, germplasm, pyrene, raspberry

\begin{abstract}
Many lesser-known wild Rubus species from Ecuador, the People's Republic of China, and North America have been obtained on recent U.S. Dept. of Agriculture plantcollecting expeditions. In this study, the seed size of 43 Rubus species was measured. An 80fold range in seed weight was observed within the genus. Asian species in the subgenera Idaeobatus and Malachobatus had the lightest seed, ranging from $0.3 \mathrm{mg}$ (R. eustephanus Focke ex Diels) to $1.2 \mathrm{mg}$ ( $R$. coreanus Miq.). The seeds of $\approx 80 \%$ of the species examined weighed $<2 \mathrm{mg}$. Seeds of European species in the subgenera Idaeobatus and Rubus (formerly Eubatus of Focke) ranged from 1.3 to $3.0 \mathrm{mg}$. The South American Orobatus included several of the heaviest-seeded species. Rubus megalococcus Focke (subgenus Rubus) had the heaviest and largest seed weighing $24.2 \mathrm{mg}$. Seed weight was not related to ploidy level in wild species. Seed weight and length were positively correlated. Seed flatness was not related to seed length. Several of the smaller-seeded Asian species, such as $R$. minusculus A. Lev. \& Van., $R$. hirsutus Thunb., and $R$. eustephanus, had more drupelets per fruit than did those of larger-seeded species. This heritable trait may be useful in breeding for increased fruit size.
\end{abstract}

The U.S. Dept. of Agriculture (USDA) recently has sponsored expeditions to collect Rubus within Ecuador, the People's Republic of China, and North America. Many species collected during these trips represent taxa previously unavailable to American small-fruit researchers (Ballington et al., 1991, 1993; Thompson, 1991, 1992). The USDA's National Clonal Germplasm Repository, Corvallis, Ore., preserves these and additional species as seedlots and plants. While fruit of these wild species are unsuitable for direct commercial production, they need to be evaluated for specific characters to determine which qualities may benefit Rubus improvement. The repository will be collaborating with many scientists to evaluate these species and is beginning this effort by examining seed characteristics.

The seed size of cultivated Rubus is significant to the processing industry and for freshmarket production (Darrow and Sherwood, 1931; Moore et al., 1973). Size can be measured by mass (Darrow and Sherwood, 1931; Petersen, 1921) or by length dimensions (Churchill et al., 1991, 1992). Fruit with high pulp : seed ratios or with small, flat seeds are

Received for publication 4 Feb. 1994. Accepted for publication 18 Apr. 1994. This research was funded by U.S. Dept. of Agriculture-Agricultural Research Service Current Research Information System 535821000-011-00D. The cost of publishing this paper was defrayed in part by the payment of page charges. Under postal regulations, this paper therefore must be hereby marked advertisement solely to indicate this fact.

'Research Leader/Curator.

${ }^{2}$ Graduate Research Assistant.
The objective of this study was to determine seed weight and dimensions for a broad range of Rubus species and contrast these measurements with known North American and European blackberries (subgenus Rubus) and raspberries (subgenus Idaeobatus).

\section{Materials and Methods}

From 1988 through 1993, seeds of 43 wild Rubus species were collected as ripe fruit, cleaned, packaged, labeled, and stored at $-20 \mathrm{C}$ upon receipt. Five replicates of 100 seeds were counted and weighed, except for three species where fewer than 500 seeds were available. Analysis of variance (ANOVA) was performed on the replicate weights. Mean separation was determined by least significant difference (LSD). The physical properties of drupelets were not examined because United States quarantine requirements state that foreign Rubus seed must be cleaned before entry into this country.

Seed size of economically important $R u$ bus cultivars has been reported by Darrow and Sherwood (1931) and Moore et al. (1973). However, this information has not been compiled for many wild species. Seed dimensions were measured for 10 taxa representing the range of seed weight. Length (longitudinal axis), width, and thickness (transverse plane) were measured with electronic calipers on 10 randomly chosen seeds of each taxon. The seed length : thickness ratio $\left(\mathrm{R}_{\mathrm{l} / \mathrm{t}}\right)$ was calculated. ANOVA and mean separation (determined by LSD) were performed on the seed dimensions and $\mathrm{R}_{1 / t}$. Seed weight and length were correlated.

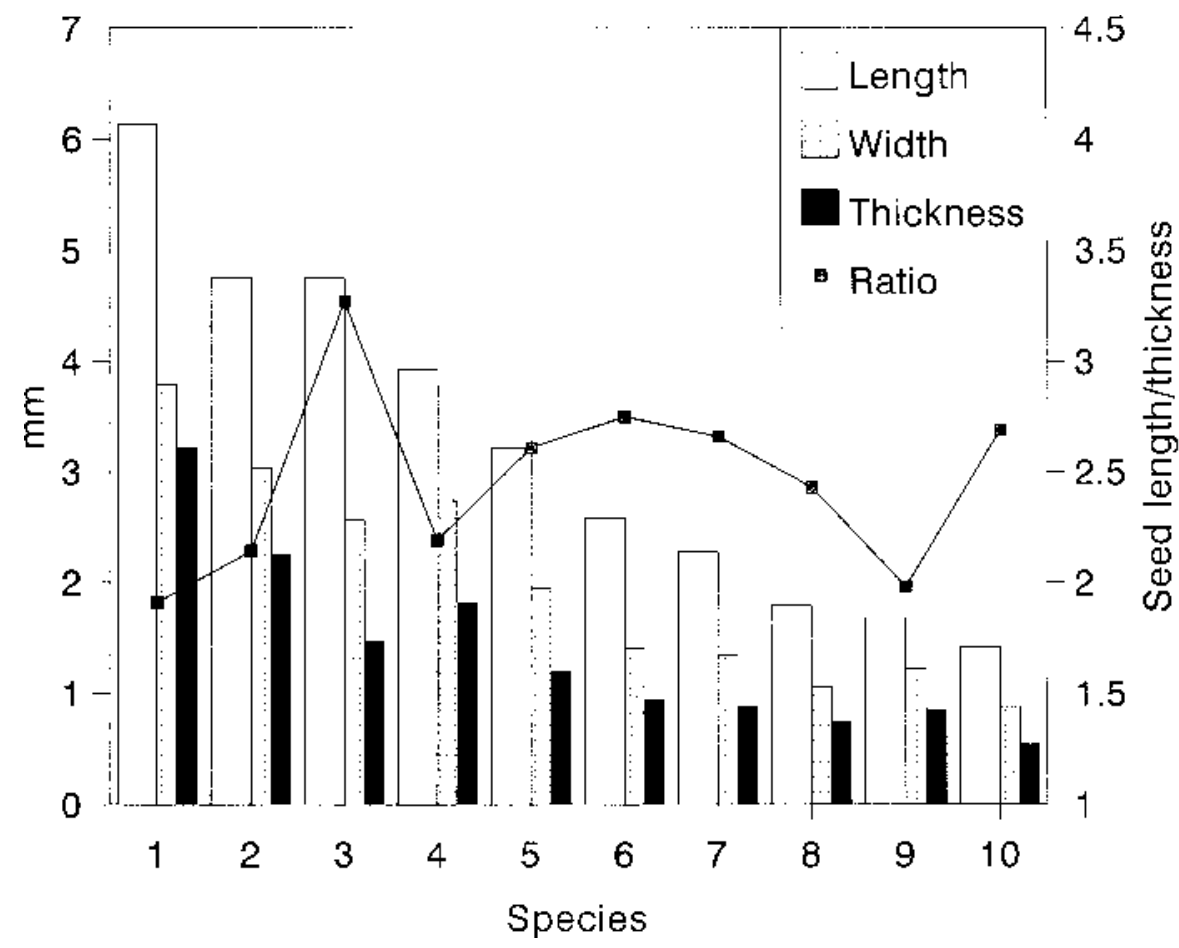

Fig. 1. Seed length, width, and thickness (Y1 axis) and the seed length : thickness ratio ( $\mathrm{R}_{\mathrm{l} / \mathrm{t}}, \mathrm{Y} 2$ axis) for 10 Rubus species. Each bar or point represents the mean of 10 seeds. The species represented are 1) $R$. megalococcus, 2) $R$. bogotensis, 3) $R$. nubigenus, 4) $R$. chamaemorus, 5) $R$. procerus, 6) $R$. idaeus, 7) $R$. chingii, 8) R. ellipticus, 9) $R$. innominatus, 10) R. eustephanus. 


\section{Results and Discussion}

The weight and length of seeds differed significantly among Rubus species (Fig. 1, Table 1). Seeds of two Ecuadorian species, $R$. megalococcus Focke and $R$. bogotensis H.B.K., were significantly heavier and longer than the heaviest-seeded species, $R$. meglococcus, was $24.2 \mathrm{mg}$, while the next-heaviest seeds $(9.5 \mathrm{mg}$ ) were of $R$. bogotensis H.B.K. (Table 1). Seeds of $R$. nubigenus H.B.K. from Ecuador and $R$. chamaemorus L. from Alaska were heavier $(7.4 \mathrm{mg})$ than those of most species examined. These seeds also were longer, wider, and thicker than those of other species (Fig. 1). Seed length was correlated positively with seed weight $(r=0.91, P<0.01)$.

The average seed weight of European and North American blackberry and raspberry species ranged from 1.3 to $2.7 \mathrm{mg}$. Seeds of both allegheniensis Porter and $R$. ursinus Cham. \& Schldl. and of the European blackberries $R$. those of other Rubus. The average weight of the North American blackberries $R$.

procerus Muller and $R$. caesius L. were larger than those of the European raspberry R. idaeus L. (Table 1). Peterson (1921) observed that seed weight of blackberry species from the northeastern United States ranged from 1.59 to $3.86 \mathrm{mg}$. Rubus procerus seeds were longer and thicker than those of $R$. idaeus (Fig. 1).

Rubus ploidy ranges from diploid (Jennings, 1988) to 14-ploid (Nybom, 1986). Seed size is not related to ploidy level. Seeds of wild diploid $R$. allegheniensis are lighter than seeds of the many cultivated tetraploid blackberry selections of the same species. Moore et al. (1973) reported that seeds of the cultivated blackberry weigh up to $4.3 \mathrm{mg}$. Similarly, seeds of diploid Arctic raspberry species are much lighter than those of the octoploid $R$. chamaemorus, native to the same region (Table $1)$. However, the seed weight of most other Rubus species is unrelated to ploidy. For example, many of the smallest-seeded species are diploid, but seed of the second-heaviest species also is diploid. Both $R$. roseus and $R$. nubigenus are members of the subgenus

Table 1. Seed weight of selected Rubus species, ordered from heavy to light. ${ }^{7}$

\begin{tabular}{|c|c|c|c|}
\hline $\begin{array}{l}\text { Corvallis } \\
\text { accession no. }\end{array}$ & Species & Collection location & $\begin{array}{c}\text { Seed wt } \\
(\mathrm{mg} / \mathrm{seed})\end{array}$ \\
\hline 1268 & R. megalococcus Focke ${ }^{y}$ & Azuay, Ecuador & $24.2 \mathrm{a}$ \\
\hline 1280 & R. bogotensis H. В. К. & Loja, Ecuador & $9.5 \mathrm{~b}$ \\
\hline 1249 & R. nubigenus H. В. К. & Carchi, Ecuador & $7.4 \mathrm{c}$ \\
\hline 1757 & R. chamaemorus L. & Alaska, USA & $7.4 \mathrm{c}$ \\
\hline 1262,1270 & R. glabratus Kunth & Carchi, Ecuador & $3.7^{x}$ \\
\hline 397 & $R$. procerus Muller & Oregon, USA & $3.0 \mathrm{~d}$ \\
\hline 1234 & R. caesius L. & Tajikistan & $2.7 \mathrm{e}$ \\
\hline 495 & R. allegheniensis Porter & Wisconsin, USA & $2.7 \mathrm{e}$ \\
\hline 1266 & $R$. roseus Poir. & Carchi, Ecuador & $2.4 \mathrm{e}$ \\
\hline $1252,1255,1258$ & R. coriaceus Poir. & Carchi, Ecuador & $2.3^{\mathrm{w}}$ \\
\hline 185 & R. ursinus Cham. \& Schldl. & Oregon, USA & $2.1 \mathrm{f}$ \\
\hline 1248 & $R$. robustus C. Presl. & Carchi, Ecuador & $1.8 \mathrm{~g}$ \\
\hline 239 & R. idaeus L. & Scotland, UK & $1.7 \mathrm{gh}$ \\
\hline 407 & R. glaucus Benth. & Hawaii, USA & $1.7 \mathrm{~h}$ \\
\hline 399 & R. hawaiiensis A. Gray & Hawaii, USA & $1.5 \mathrm{i}$ \\
\hline 1250 & R. adenothallus Focke & Carchi, Ecuador & $1.5 \mathrm{ij}$ \\
\hline 626 & $R$. sachalinensis A. Leveille & Jilin, China & $1.5 \mathrm{ij}$ \\
\hline 186 & R. parviflorus Nutt. & Oregon, USA & $1.4 \mathrm{jk}$ \\
\hline 822 & R. caucasicus Focke & Russian Federation & $1.4 \mathrm{k}$ \\
\hline $1630,1634,1635$ & R. coreanus Miq. & Guizhou, China & 1.21 \\
\hline 1658 & R. parvifolius L. & Guizhou, China & $1.1 \mathrm{~lm}$ \\
\hline 1277 & R. urticifolius Poiret & Zamora, Ecuador & $1.0 \mathrm{mn}$ \\
\hline 1620,1035 & R. chingii $\mathrm{Hu}$ & Jiangsu, China & $1.0 \mathrm{mn}$ \\
\hline 1671 & R. swinhoei Hance & Guizhou, China & $1.0 \mathrm{mn}$ \\
\hline 1064,1061 & R. hoffmeisterianus Knth \& Bche & Gilgit, Pakistan & 0.9 no \\
\hline $1073,1068,1650$ & $R$. niveus Thunb. & Swat, Pakistan & 0.9 no \\
\hline 175 & R. kawakamii Hayata & Taiwan & 0.8 op \\
\hline 178 & R. hayata-koidzumii Naruhashi & Taiwan & 0.8 op \\
\hline 1645,1642 & R. multibracteatus A. Lev. \& Van. & Guizhou, China & $0.7 \mathrm{pq}$ \\
\hline 246 & R. lasiostylus Focke & Asia (through UK) & $0.7 \mathrm{p}-\mathrm{r}$ \\
\hline 1039 & R. innominatus S. Moore & Jiangxi, China & $0.7 \mathrm{qr}$ \\
\hline 160,627 & $R$. crataegifolius Bunge & China & $0.7 \mathrm{qr}$ \\
\hline 158 & R. microphyllus L. & Japan & $0.7 \mathrm{qr}$ \\
\hline $181,1183,1710$ & R. lambertianus Ser. & Jiangsu, China & $0.7 \mathrm{qr}$ \\
\hline 174 & R. formosensis Kuntze & Taiwan & $0.6 \mathrm{rs}$ \\
\hline 1695 & R. setchuenensis Bureau \& Fran. & Guizhou, China & $0.5 \mathrm{st}$ \\
\hline 1665 & R. pinfaensis A. Lev. \& Van. & Guizhou, China & $0.5 \mathrm{st}$ \\
\hline 394 & R. ellipticus Smith & Nepal & $0.5 \mathrm{st}$ \\
\hline 1628 & $R$. corchorifolius $\mathrm{L}$. & Guizhou, China & 0.5 tu \\
\hline 188 & $R$. rosifolius Smith & Java, Indonesia & $0.3 \mathrm{uv}$ \\
\hline 161 & R. minusculus A. Lev. \& Van. & Japan & $0.3 \mathrm{v}$ \\
\hline $1040,1037,1038$ & R. hirsutus Thunb. & Jiangsu, China & $0.3 \mathrm{v}$ \\
\hline 1638,1639 & R. eustephanus Focke ex Diels & Guizhou, China & $0.3 \mathrm{v}$ \\
\hline
\end{tabular}

${ }^{\mathrm{z}}$ Mean of five replications of 100 seeds, mean separation by LSD, $P \leq 0.05$.

y Mean of five replicates of 50 seeds.

'Insufficient seed for analysis of variance (ANOVA); mean of 91 seeds.

wInsufficient seed for ANOVA; mean of 80 seeds.
Orobatus. Ploidy level for these species is unpublished. The seeds of $R$. roseus weigh less than one-third those of $R$. nubigenus. Seeds of $R$. glabratus, another Orobatus whose ploidy is unknown, weigh less than one-third those of $R$. roseus. Ploidy of the heaviestseeded species, $R$. megalococcus (subgenus Rubus), is unreported.

The seeds of $>80 \%$ of the species examined weighed $<2 \mathrm{mg}$. Some of the smallerseeded species included the Asian diploids $R$. eustephanus Focke ex Diels, R. hirsutus Thunb., $R$. minusculus A. Lev. \& Van., $R$. rosifolius Smith, and $R$. corchorifolius L. Darrow and Sherwood (1931) pointed out that black raspberries seem seedy because the seeds, though small, are numerous. They concluded that seed size is only one of the factors contributing to seediness and that the proportion of seed weight to the total berry weight is more important than the seed size. These authors were referring to the cultivated raspberries and blackberries and not to the extremely largeseeded species: R. megalococcus, R. bogotensis, $R$. nubigenus, and $R$. chamaemorus.

We did not examine the seeds of $R$. occidentallis L. or R. leucodermis Doug. ex Tor. \& Gray, the North American black raspberries, but the small-seeded Asian species of this study with high numbers of drupelets were of similar "seediness." While these species would have limited use for processors or fresh market, they may be of significance to berry breeders. One breeding strategy to increase fruit size includes preliminary crosses with wild species to increase the number of drupelets per fruit. The small-seeded Asian species would be good initial candidates for such a project. Moore et al. (1975) showed that seed size in blackberry is highly heritable and that small seededness is partly dominant.

Seed flatness of 10 Rubus species was not related to seed length (Fig. 1). Seed length varied from $>3$ to $<2$ times the thickness. Rubus nubigenus (species 3 ) and $R$. idaeus (species 6) had the largest $\mathrm{R}_{\mathrm{l} / \mathrm{t}}$ values, i.e., the thinnest seeds for their length (Fig. 1). While $R$. nubigenus had the highest seed $\mathrm{R}_{1 / /}$, its seeds were thicker than the length of seeds of most species tested. The $\mathrm{R}_{1 / t}$ of $R$. eustephanus (the smallest seed), $R$. chingii, and $R$. procerus was $<3$. In contrast, the $\mathrm{R}_{1 / \mathrm{t}}$ of $R$. megalococcus (the largest seed), $R$. innominatus, $R$. bogotensis, and $R$. chamaemorus was $\approx 2$ (Fig. 1 ). This second group of seeds was more "round" than "flat" in cross section.

Generally, the heaviest seeds were members of the South American subgenera Rubus and Orobatus, although the monotypic, circumpolar-boreal subgenus Chamaemorus also had large seeds. Seeds of species in the economically important subgenus Rubus were slightly heavier than those of the European Idaeobatus. The Asian Idaeobatus and Malachobatus species had the lightest, shortest seeds.

In summary, the seeds of $R$. megalococcus, $R$. bogotensis, $R$. nubigenus, and $R$. chamaemorus were heavier and longer than those of other Rubus. We observed an 80-fold range in seed weight among species within the 
genus. About $80 \%$ of species had seeds that weighed $<2 \mathrm{mg}$. Seeds of blackberry species were longer and thicker than those of raspberry species. Many Asian species had smaller seeds than those of the European red raspberry $R$. idaeus. While seed length and weight were correlated, seed length was not related to seed flatness. Seed weight is not related to the ploidy level of wild Rubus species.

\section{Literature Cited}

Ballington, J.R., J.L. Luteyn, and M.M. Thompson. 1991. Small fruit germplasm resources in the Andean region of Ecuador. Hort. Crops Res. Ser. 91. North Carolina State Univ., Raleigh.

Ballington, J.R., J.L. Luteyn, M.M. Thompson, K. Romoleroux, and R. Castillo. 1993. Rubus and
Vacciniaceous germplasm resources in the Andes of Ecuador. Food Agr. Organization, Intl. Board Plant Genet. Resources Plant Genet. Resources Nwsl. 93:9-15.

Churchill, D.B., D.M. Bilsland, and T.M. Cooper. 1991. Rotating table for measuring seed physical properties. Trans. Amer. Soc. Agr. Eng. 34(4):1842-1845.

Churchill, D.B., D.M. Bilsland, and T.M. Cooper. 1992. Comparison of machine vision with human measurement of seed dimensions. Trans. Amer. Soc. Agr. Eng. 35(1):61-64.

Darrow, G.M. and H. Sherwood. 1931. Seed and berry size of cane fruits. Proc. Amer. Soc. Hort. Sci. 28:194-199.

Jennings, D.L. 1988. Raspberries and blackberries: Their breeding diseases and growth. Academic, London.

Moore, J.N., G.R. Brown, and E.D. Brown. 1973. Relationships between fruit size and seed number and size in blackberries. Fruit Var. J. 40-45.

Moore, J.N., C. Lundergan, and E.D. Brown. 1975. Inheritance of seed size in blackberry. J. Amer. Soc. Hort. Sci. 100(4):377-379.

Nybom, H. 1986. Chromosome numbers and reproduction in Rubus subgenus Malachobatus. Plant Syst. Evol. 152:211-218.

Petersen, A.K. 1921. Blackberries of New England, genetic status of the plants. Vermont Agr. Expt. Sta. Bul. 218.

Thompson, M.M. 1991. Notes on Rubus from Ecuador exploration trip. Sta. Rpt. U.S. Dept. Agr.Agr. Res. Serv., Natl. Clonal Germplasm Repository, Corvallis, Ore.

Thompson, M.M. 1992. Exploration for Rubus germplasm in Guizhou Province, People's Republic of China. Sta. Rpt. U.S. Dept. Agr.-Agr. Res. Serv., Natl. Clonal Germplasm Repository, Corvallis, Ore. 